\title{
Consumption as a Factor of Polish Economic Growth During the Global Recession of 2008/2009: A Comparison with Spain and Hungary
}

\author{
Tomasz Jasiński \& Paweł Mielcarz
}

\begin{abstract}
The economic recession of 2007-2009 proved to be a difficult period for most European economies. Poland was among the few countries that recorded positive gross domestic product (GDP) growth during that period. The main reason for its performance was that private consumption stimulated the GDP. The goal of this study was to explore the reasons that private consumption in Poland did not collapse during the economic recession through the substantial economic literature on this topic. The study compared Spain, Hungary and Poland from 2007 to 2009 to find differences specific to the latter. The most important factors differentiating Poland identified in this study were the confidence of Polish consumers in the economy and a high propensity to spend resulting in lower savings. Additional factors were a relatively low unemployment rate and relatively easy access to credit.
\end{abstract}

KEY WORDS: $\quad$ Poland; Spain; Hungary; GDP growth; consumption

JEL Classification: G11, G12, G15

${ }^{1}$ Akademia Leona Koźmińskiego, Poland

\section{Introduction}

During the economic recession beginning in 2007, the vast majority of EU countries reported experiencing an economic contraction (Euromonitor, 2011). Economic data indicated that Poland's consumption level was the main factor differentiating it from other EU countries. It is worthwhile to explore this phenomenon to determine why the consumption level was so robust in Poland while other EU countries experienced dramatic declines in private spending.

The main goal of this study is to determine the factors that led to Poland's atypical consumption level

Correspondence concerning this article should be addressed to: Tomasz Jasiński, Akademia Leona Koźmińskiego ul. Jagiellońska 57/59, 03-301 Warsaw, Poland, e-mail: thetomaszjasinski@gmail.com during the economic recession of 2007-2009. This will be achieved through a comparative analysis of Poland and two other European Union member states. One of these countries is already well established within the EU structure and bears a resemblance to Poland in terms of size and population (i.e., Spain). The other is, as is Poland, a relatively new member of the European Community, shares a history of communism and is also located in the Central Eastern Europe region (i.e., Hungary). Conclusions will be reached after answering the following research questions:

- Which factors differentiated Polish consumption from that of comparable EU countries in 20072009 ?

- How relevant are the existing theories on consumption components in relation to the actual data? 
The second goal is to compare and contrast consumption patterns in those three countries. Finally, this study seeks to identify potential areas for further research based on the initial findings of this article.

\section{Consumption and Its Determinants}

The research was a retrospective study focused on the 2007-2009 period and the determinants influencing consumption patterns in the selected countries. The research was primarily based on available secondary data published by national statistics offices, Eurostat, the World Bank, the World Trade Organization, the Organization for Economic Cooperation and Development, the International Monetary Fund and other similar institutions.

The economic literature does not provide a single, common definition of consumption. However, the consensus is that consumption is a process (Zalega, 2007, p. 12) that results in the satisfaction of needs. Those needs can be fulfilled by the intake or usage, over a period of time, of a certain good or service. For the purposes of this study, consumption will be defined as the utilization of economic goods in the satisfaction of wants or in the process of production resulting chiefly in their destruction, deterioration, or transformation (Merriam-Webster's $11^{\text {th }}$ Collegiate Dictionary 2004, entry: consumption). This definition is well connected to the economic meaning of consumption, meaning transforming one's share of income into goods and services.

Consumption alone amounted to approximately $57 \%$ of the EU's GDP creation from 1996 to 2006 (Dreger \& Reimers, 2006, p. 2). As it plays a major role in GDP creation, it seems reasonable to begin by identifying the factors that influence it and will later be used as the basis for the cross-country comparison. Identified factors include:

- Disposable income;

- Expectations of the future;

- Influence of the shadow economy.

These factors are described below along with their respective characteristics and sources of influence and were also used in the empirical analysis.

\section{Disposable Income}

For consumption to be possible, there must be money to spend. Such free resources are called disposable income. This value represents how much a household is actually able to spend as it pleases (Samuelson \& Nor- dhaus, 1992, p. 231). It is obtained by subtracting taxes from income and adding transfer payments from the government. Each household can either spend (consume) or save the money it receives.

There is evidence of a long-run relationship between disposable income and consumption (Paap \& van Dijk, 2003, p. 4). Data analyzed for the U.S. suggest that there is a linear relationship between the two values. Moreover, as the research indicates, "the growth rate in consumption is larger than the negative growth rate in income during recessions... even expected income growth in the market sector predicts growth in market consumption" (Baxter \& Jermann, 1999, p. 3). This is especially important for the analysis of the economic downturn conducted in this study.

When analyzing disposable income, it is important to highlight the role of private savings. Although decreased saving rates mean that a household is able to consume more, there is evidence from South Africa that a very low level of private savings may, in the medium-run, "hinder investment driven growth" and "...falling saving rates imply reliance on foreign capital inflows" (Aron \& Muellbauer, 2000, p. 3). Moreover, "borrowing or saving allows consumption smoothing" (Jenkins, 2000, p. 4). It is important to note that "due to a shortage of household data, most work on saving has used only aggregate data" (Schmidt-Hebbel, Webb \& Corsetti, 1992, p. 9). It is significant "that most determinants of savings identified in the literature also apply to transition economies" (Chowdhury, 2004, p. 1).

\section{Expectations}

Economists have widely confirmed the impact of expectations on private consumption (Stephens, 2004, p. 3). These expectations may be measured using the Consumer Confidence Index (CCI), which refers to a key determinant of near-term economic growth (Ludvigson, 2004, p. 2). Expected job losses are one of the factors influencing the consumption level. It would seem that to prepare themselves for a future job loss shock, households decrease consumption and revert to saving. Although there is a significant correlation between job loss expectations and actual job loss, the expectations do not noticeably influence household consumption patterns (Stephens, 2004, p. 5). This may help to explain why certain patterns did not change during the substantially uncertain period of 2007-2009. Similarly, 
In addition to expectations concerning job stability, the analysis of unemployment rates may be helpful due to the assumption that high unemployment will result in lower consumption, leading to a smaller contribution towards GDP formation. The negative relationship between unemployment and consumption is believed to be expectations based (Barhoumi et. al., 2007, p. 3). It is also believed that "economic growth is the panacea solution for unemployment" (Wolnicki, Kwiatkowki \& Piasecki, 2006, p. 1). Thus, it can be assumed that relatively low unemployment should be associated with relatively high GDP growth.

The economic literature regards the role of expectations as vital: "Economic theory without an explanation of expectations will not be able to contribute towards an understanding of macroeconomic phenomena" (Kantor, 1979, p. 17).

\section{Shadow Economy}

It is important to note that all of the theories presented herein are based on official data. Unfortunately, "crime and shadow economic activities are a fact of life around the world" (Schneider, 2005, p. 2). It appears logical to begin with a working definition of what a shadow economy (also known as black market or black economy) is. It is described as a "market-based production of goods and services, whether legal or illegal, that escapes detection in the official estimates of GDP" (Smith, 1994, p. 3). It involves activities such as illegal drug trafficking, counterfeiting, piracy and prostitution. Thus, it is a market of banned goods. It can also represent income received from illegal activities, e.g., bribery or tax evasion.

An obvious consequence of black economy activities are distortions in the available national statistics, as those involved would rather remain anonymous, and this lowers reported government income. However, Schneider (2005, p. 3) claims that the shadow economy has a positive influence on a country's official economy by smoothing the effect of any shocks during economic downturns, such as the recession of 2007-2009. During periods of economic destabilization, those affected can enter the shadow economy more easily than the official economy. The reasons are the lack of legal constraints or regulations and low entry costs. Therefore, although a country may report an economic slowdown, business activities are still being conducted, although they are unregistered.
It is vital to note that activities in the shadow economy, although cushioning temporary shocks, decrease tax income. This can result in decreases in the quantity and quality of public goods, which may not be beneficial in the long run. "Empirical findings ... show that over 66 percent of earnings in the shadow economy are immediately spent in the official sector" (Schneider \& Enste, 2000, p. 8). This is the primary reason that this phenomenon is being described in relation to consumption in this study. The assumption is that most, if not all, gains in the shadow economy are transferred into official consumption.

Due to its nature, it is difficult to obtain verifiable estimates of activity in the shadow economy. Schneider and Enste (2000, p. 10) used direct and indirect approaches. The direct approach is based on questioning and extracting data directly from the society. Although this approach can deliver quite detailed data, it is constrained by the respondents' willingness to provide true answers. Indirect approaches (also known as indicator approaches) are based on macroeconomic indicator analysis, such as comparing income and expenditures, discrepancies in labor market data or energy consumption. Therefore, the greatest limitation is that any data provided are derived from "guess-timating" (Thomas, 1999, p. 5), meaning making an educated guess based on indirect data.

Table 1 provides a brief summary of the theories presented in this section.

\section{Methodology and limitations}

The first step of the study was a literature review concerning global consumption behavior. The aim of the following section is to identify the factors influencing the levels and patterns of consumption behaviors. This provided the theoretical framework used in the analysis. The next section presents a comparative analysis based on the secondary data. Finally, the last section presents the study's conclusions, highlighting the differences between Poland and the two comparison countries.

This article should be regarded as initial study of a broader phenomenon. Its findings could be used in the process of designing detailed econometric studies concerning each aspect of consumption with respect to recessions in the context of the Spanish, Hungarian and Polish economies. 
Table 1. Summary of Factors Influencing GDP Components

\begin{tabular}{llll}
\hline GDP Component & Author/s & Impact \\
\hline & Disposable Income & $\begin{array}{l}\text { Samuelson and } \\
\text { Nordhaus (1992) }\end{array}$ & $\begin{array}{l}\text { The greater the disposable income, the higher the } \\
\text { consumption } \\
\text { Expectations }\end{array}$ \\
$\begin{array}{lll}\text { Private } \\
\text { Consumption }\end{array}$ & $\begin{array}{l}\text { Stephens (2004) } \\
\text { Shneider (2000) }\end{array}$ & $\begin{array}{l}\text { The more positive the expectations of future incomes } \\
\text { (employment), the higher current consumption }\end{array}$ \\
& Shadow Economy & Smith (1994) & $\begin{array}{l}\text { More developed grey market may dampen negative } \\
\text { effects on consumption }\end{array}$ \\
& Thomas (1999) & \\
\hline
\end{tabular}

Table 2. Consumption and GDP Growth (Eurostat 2011)

\begin{tabular}{l|rrr|rcc|ccc}
\hline \multicolumn{1}{c}{ Consumption } \\
\hline Country & \multicolumn{3}{c|}{ Hungary } & \multicolumn{3}{c}{ Spain } & \multicolumn{3}{c}{ Poland } \\
\hline Year & 2007 & $\mathbf{2 0 0 8}$ & $\mathbf{2 0 0 9}$ & $\mathbf{2 0 0 7}$ & $\mathbf{2 0 0 8}$ & $\mathbf{2 0 0 9}$ & $\mathbf{2 0 0 7}$ & $\mathbf{2 0 0 8}$ & $\mathbf{2 0 0 9}$ \\
\hline Consumption/GDP & $54,09 \%$ & $52,08 \%$ & $51,41 \%$ & $57,37 \%$ & $52,32 \%$ & $52,05 \%$ & $60,62 \%$ & $60,79 \%$ & $61,33 \%$ \\
Consumption change & $\mathrm{n} / \mathrm{a}$ & $0,40 \%$ & $-7,90 \%$ & $\mathrm{n} / \mathrm{a}$ & $-0,60 \%$ & $-4,20 \%$ & $\mathrm{n} / \mathrm{a}$ & $5,30 \%$ & $2,60 \%$ \\
Real GDP growth & $0,80 \%$ & $0,80 \%$ & $-6,70 \%$ & $3,60 \%$ & $0,90 \%$ & $-3,70 \%$ & $6,80 \%$ & $5,10 \%$ & $1,70 \%$ \\
\hline
\end{tabular}

Table 3. Consumption Distribution is Spain 2007-2009 (Spanish Statistical Office 2011)

\begin{tabular}{|c|c|c|c|}
\hline \multicolumn{4}{|c|}{ Consumption distribution in Hungary } \\
\hline Consumer Expenditure & 2007 & 2008 & 2009 \\
\hline Total & $100,00 \%$ & $100,00 \%$ & $100,00 \%$ \\
\hline Food and Non-Alcoholic Beverages & $13,61 \%$ & $13,40 \%$ & $13,23 \%$ \\
\hline Alcoholic Beverages and Tobacco & $3,12 \%$ & $3,13 \%$ & $3,14 \%$ \\
\hline Clothing and Footwear & $4,96 \%$ & $4,81 \%$ & $4,65 \%$ \\
\hline Housing & $16,62 \%$ & $16,89 \%$ & $17,22 \%$ \\
\hline Household Goods and Services & $5,02 \%$ & $4,92 \%$ & $4,80 \%$ \\
\hline Health Goods and Medical Services & $3,68 \%$ & $3,74 \%$ & $3,80 \%$ \\
\hline Transport & $12,05 \%$ & $11,99 \%$ & $11,88 \%$ \\
\hline Communications & $2,79 \%$ & $2,88 \%$ & $2,96 \%$ \\
\hline Leisure and Recreation & $9,47 \%$ & $9,60 \%$ & $9,74 \%$ \\
\hline Education & $1,36 \%$ & $1,32 \%$ & $1,28 \%$ \\
\hline Hotels and Catering & $19,28 \%$ & $19,37 \%$ & $19,45 \%$ \\
\hline Miscellaneous Goods and Services & $8,04 \%$ & $7,94 \%$ & $7,85 \%$ \\
\hline
\end{tabular}


Table 4. Consumption Distribution in Hungary 2007-2009 (Hungarian Statistical Office 2011)

\begin{tabular}{|c|c|c|c|}
\hline \multicolumn{4}{|c|}{ Consumption distribution in Hungary } \\
\hline Consumer Expenditure & 2007 & 2008 & 2009 \\
\hline Total & $100,00 \%$ & $100,00 \%$ & $100,00 \%$ \\
\hline Food and Non-Alcoholic Beverages & $17,28 \%$ & $17,49 \%$ & $17,58 \%$ \\
\hline Alcoholic Beverages and Tobacco & $9,44 \%$ & $9,93 \%$ & $9,96 \%$ \\
\hline Clothing and Footwear & $3,47 \%$ & $3,33 \%$ & $3,40 \%$ \\
\hline Housing & $19,12 \%$ & $19,28 \%$ & $19,75 \%$ \\
\hline Household Goods and Services & $5,77 \%$ & $5,55 \%$ & $5,25 \%$ \\
\hline Health Goods and Medical Services & $3,55 \%$ & $3,43 \%$ & $3,38 \%$ \\
\hline Transport & $15,61 \%$ & $15,54 \%$ & $15,51 \%$ \\
\hline Communications & $3,98 \%$ & $3,92 \%$ & $3,43 \%$ \\
\hline Leisure and Recreation & $7,57 \%$ & $7,36 \%$ & $7,37 \%$ \\
\hline Education & $1,11 \%$ & $1,08 \%$ & $1,07 \%$ \\
\hline Hotels and Catering & $5,21 \%$ & $5,08 \%$ & $5,26 \%$ \\
\hline Miscellaneous Goods and Services & $7,91 \%$ & $8,00 \%$ & $8,05 \%$ \\
\hline
\end{tabular}

Table 5. Consumption Distribution in Poland 2007-2009 (Polish Statistical Office 2011)

\begin{tabular}{|c|c|c|c|}
\hline \multicolumn{4}{|c|}{ Consumption distribution in Poland } \\
\hline Consumer Expenditure & 2007 & 2008 & 2009 \\
\hline Total & $100,00 \%$ & $100,00 \%$ & $100,00 \%$ \\
\hline Food and Non-Alcoholic Beverages & $20,59 \%$ & $20,43 \%$ & $20,33 \%$ \\
\hline Alcoholic Beverages and Tobacco & $6,56 \%$ & $6,55 \%$ & $6,54 \%$ \\
\hline Clothing and Footwear & $4,52 \%$ & $4,47 \%$ & $4,41 \%$ \\
\hline Housing & $23,98 \%$ & $24,13 \%$ & $24,28 \%$ \\
\hline Household Goods and Services & $4,36 \%$ & $4,35 \%$ & $4,35 \%$ \\
\hline Health Goods and Medical Services & $4,04 \%$ & $4,07 \%$ & $4,10 \%$ \\
\hline Transport & $8,46 \%$ & $8,35 \%$ & $8,22 \%$ \\
\hline Communications & $3,37 \%$ & $3,44 \%$ & $3,50 \%$ \\
\hline Leisure and Recreation & $7,27 \%$ & $7,26 \%$ & $7,19 \%$ \\
\hline Education & $1,29 \%$ & $1,29 \%$ & $1,27 \%$ \\
\hline Hotels and Catering & $2,82 \%$ & $2,81 \%$ & $2,79 \%$ \\
\hline Miscellaneous Goods and Services & $12,73 \%$ & $12,87 \%$ & $13,02 \%$ \\
\hline
\end{tabular}


The authors also acknowledge that future studies could focus on other policy-making contexts in each of the countries considered here, which would improve understandings of the causes of some of the findings.

\section{Empirical Analysis}

This section analyzes the factors identified in the literature review as influencing consumption. An analysis of the data should identify factors that are specific to Poland and that helped to sustain its private consumption during the recession of 2007-2009.

\section{Consumption Patterns in Spain, Hungary and Poland}

As discussed in section 3, consumption plays a significant role in GDP creation. This is why it is described here as the first component of GDP and why a comprehensive analysis is required to describe it. It seems reasonable to begin with an analysis of private consumption with respect to GDP in the respective countries.

Table 2 presents consumption levels and changes in Spain, Hungary and Poland. It appears that consumption played the greatest role in Poland and was not affected by the recession. It did not decline and even slightly increased to reach a level of $61 \%$ of GDP. However, consumption in Spain clearly declined. The Spanish economy responded more rapidly to the global economic situation than the Hungary and Poland economies, resulting in a decline in GDP by 2008. Although Hungary and Poland faced similar conditions, only the Hungarian people reacted negatively.

\section{Consumption patterns in Spain}

The rise in unemployment and GDP contraction led to an observable decline in disposable income. Spanish consumption was believed to be fuelled by a realestate bubble (Eurostat 2011). The burst of this bubble in 2008 made the recession even more painful. Table 3 presents the changes in the structure of Spanish consumption in this period.

First, the recession affected the housing market. Spaniards retreated from impulse purchases and some branded products, primarily foodstuffs. They began to shop more price-consciously. Retailers' brands gained in popularity because price was the greatest concern (Euromonitor, 2011). Purchases were often made in outlet shops that offered discounts of up to $50 \%$ (Euro- monitor, 2011). Table 3 depicts small downward shifts in those categories. Housing spending, which refers to rent, gas, and heating expenses' share of total consumption, increased. Due to high unemployment and lower disposable income, Spanish restaurants suffered. Although Spaniards tended to eat out less frequently, they spent similar shares of their incomes on hotels and catering as they had before (see Table 3). This means that, as with other products, they simply substituted less expensive alternatives, such as fast food.

To conclude, as overall nominal consumption in Spain decreased over the observed period, the consumption patterns (i.e., each consumption category as a percentage of total consumption) did not change significantly.

\section{Consumption patterns in Hungary}

Hungary began 2007 with sluggish car sales and a declining the restaurant sector (Euromonitor, 2011). More important, consumers had pessimistic attitudes about the future. In 2008, they "... believe that it is not worth trusting anyone or planning for the future" (Euromonitor, 2011). In 2008, Hungary was declared the most pessimistic country in the European Union. This situation only deteriorated further in 2008. Hungarians were already reducing their spending.

Hungarian consumption has declined consistently since 2006. In 2008, consumer consumption fell by 7.9\% (see Table 2). Moreover, contractions were reported in nearly all demand sectors in Hungary (Hungarian Office of Statistics, 2011). Table 4 depicts Hungarian consumption patterns throughout the period considered. It is worth highlighting that primary consumption categories in Hungary and Spain differ. The greatest share of Hungarian expenditures was devoted to housing (rent and utilities), food and transport (i.e., commuting). As nominal consumption declined and consumption patterns were not significantly affected, it can be deduced that Hungarians also shifted to less expensive, alternative goods.

\section{Consumption patterns in Poland}

According to the Polish Office of Statistics, all consumption categories were on the increase (Polish Office of Statistics, 2011). During the period considered, there were no major changes in Polish consumption patterns, and the composition remained nearly identical (Table 5). 
Due to wage increases, Polish households (Euromonitor, 2011) were able to purchase appliances, such as dishwashers, refrigerators and electronics (mostly LCD TVs). Those categories accounted for the bulk of 2007 consumption. Early 2008 witnessed a strong Polish Zloty relative to the U.S. dollar and the Euro. This enabled Polish customers to import more goods and increase their shopping and travel abroad, especially to Spain, which reported a $31 \%$ increase in Polish tourists in 2008 (Euromonitor, 2011).

Moreover, Polish restaurant and fast-food markets did not stop developing and were expected to grow $8 \%$ annually (GFK, 2009). Based on this information, consumption in Poland remained high due to demand for non-essential goods and the lack of any significant changes in consumption patterns.

\section{Summary}

The role that consumption played in each of the studied economies seems similar to the findings presented in the theoretical review. Consumption's role in GDP formation only increased in Spain, while it fell in Spain in Hungary. As the Polish economy was the only one that did not contract, it can be assumed that nominal levels (in national currency) also increased while decreasing in the other two countries, which reported declines in GDP.

It is important to mention that consumption patterns in all three countries remained at relatively unchanged levels throughout the period considered, which covers data prior to the recession and employs 2007 as a base. It is important to note that the major expenditure categories in Poland were food, housing (which also covers utilities) and miscellaneous goods and services. These three groups accounted for approximately $20 \%, 24 \%$ and $13 \%$ of total private consumption, respectively (see Table 5). The first two groups can be treated as necessities and may simply reflect higher prices relative to earnings.

Hungarians' income allocations were similar, with food and housing representing the largest categories at $17 \%$ and $19 \%$, respectively, and transport (15\%) being the third highest. In this case, over $50 \%$ of consumption was devoted to necessities (see Table 4). This result assumes that transportation is connected to daily routines (e.g., commuting to work). Housing expenses also played an important role in Spaniards' total ex- penditures (approximately 17\%). However, this category was not as large as hotels and catering expenditures (see Table 3), which continued to represent 19\% of the total. This result demonstrates the importance of Spaniards' social lives.

The data show that the recession did not influence consumption habits in any of the observed countries. Although greater emphasis might have been placed on the price or quality of products purchased, no shifts were made to accommodate new economic conditions. Therefore, any changes in gross consumption were the result of smaller amounts of money being spent and were derived solely from nominal changes.

\section{Expectations}

The reason to begin the analysis by considering expectations is to capture the general economic attitude for each of the selected countries. This approach should help to place the other consumption factors into a more specific context, which should facilitate understanding why certain processes occurred in a given country.

Consumer expectations can be measured using the Consumer Confidence Index (CCI), which essentially reflects general optimism in a given economy $(1985=100$ points). If the unemployment rate is low and GDP growth is high, the confidence level should increase. A high CCI results in increased spending, as households feel confident about their future and income.

Spaniards were optimists before the economic recession, with a CCI at approximately 90 points throughout the first half of 2007 (Trading Economies, 2011). This was followed by a decline of 20 points. This level persisted until the end of 2007, only to fall again and remain at 50 points until February 2009. Then, a sudden rise was observable, where the CCI reached 80 points and fluctuated around this value.

Hungarians were pessimistic about the economic future even prior to the recession. In 2007, the CCI oscillated between -50 and -55 points (Trading Economies, 2011). "In late 2007, it was reported that only $8 \%$ of Hungarians had a positive outlook on their economy" (Euromonitor, 2011). The year 2008 was no different, with an observable trend of growing pessimism in the summer, which then increased further throughout that autumn and winter. The following year witnessed a further decline in attitudes, with the CCI ranging from -60 at the beginning of the year to a low of -70 . Although there 
Table 6. Disposable Income in Hungary, Spain, and Poland, 2007-2009

\begin{tabular}{l|ccc|ccc|ccc}
\hline \multicolumn{7}{c}{ Disposable Income } \\
\hline Country & \multicolumn{3}{c|}{ Hungary } & \multicolumn{3}{c}{ Spain } & \multicolumn{3}{c}{ Poland } \\
\hline Criteria/Time & $\mathbf{2 0 0 7}$ & $\mathbf{2 0 0 8}$ & $\mathbf{2 0 0 9}$ & $\mathbf{2 0 0 7}$ & $\mathbf{2 0 0 8}$ & $\mathbf{2 0 0 9}$ & $\mathbf{2 0 0 7}$ & $\mathbf{2 0 0 8}$ & $\mathbf{2 0 0 9}$ \\
\hline disposable income (PPS) & 11395 & 11395 & 11033 & 18949 & 19314 & 19235 & 10740 & 11104 & 11489 \\
\% change* & -1.8 & 0,00 & -3.2 & 2.9 & 1.9 & -0.4 & 4.6 & 3.4 & 3.5 \\
Savings (Gross) & $10,34 \%$ & $8,42 \%$ & $10,91 \%$ & $10,70 \%$ & $13,38 \%$ & $18,05 \%$ & $8,52 \%$ & $3,70 \%$ & $9,91 \%$ \\
Savings (Net)** & 4,60 & 3,00 & 3,40 & n/a & n/a & n/a & 6,10 & 0,8 & 3,30 \\
\hline
\end{tabular}

Note: Source: Eurostat; * source: OECD for 2007; ${ }^{* *}$ source: OECD

Table 7. Disposable Income in the European Union, 2007-2009

\begin{tabular}{l|ccc|}
\hline \multicolumn{3}{c}{ Disposable Income } & \\
\hline Country & & EU27 & $\mathbf{2 0 0 9}$ \\
\hline Criteria/Time & $\mathbf{2 0 0 7}$ & 19292 & 18967 \\
\hline disposable income (PPS) & 18976 & 1.7 & -1.7 \\
\% change* & n/a & $11,13 \%$ & $13,20 \%$ \\
Savings (Gross) & $10,92 \%$ & $\mathrm{n} / \mathrm{a}$ & $\mathrm{n} / \mathrm{a}$ \\
\hline Savings (Net)
\end{tabular}

Note: Source: Eurostat; ${ }^{*}$ source: OECD for 2007; *** source: OECD

were signs of recovery at the end of the year, -50 points is a rather grim figure. As with other factors, Spain was affected before Central European countries.

Not only did Polish confidence not decline from 105 points, it grew somewhat in 2008 from a figure of 115 at the beginning of the year (Trading Economies, 2011). It fell below 100 in the last quarter to 85 . The only signs of pessimism were visible in the second quarter, when the CCI reached 70 points. However, this was followed by a rapid increase. The CCI oscillated around 85 points. This figure is clearly below those observed in prior economic recessions. However, the recovery was much more rapid in Poland than in other countries.

The data show that Poles did not react with a sudden loss of confidence in 2008. Interestingly, they began to lose confidence as other countries have experienced less economic pessimism.

\section{Disposable Income} Introduction

As described in section "Methodology and limitations", disposable income influences consumption, as it represents the amount of money available to a given household to spend. It is briefly analyzed here to place the consumption patterns described in section 4.1 in a broader context.

Tables 6 and 7 present the per capita real adjusted gross disposable household income. It was obtained by dividing gross disposable income by purchasing power parities (PPP). PPP's role is to eliminate the differences in price levels between countries during the conversion process (OECD, 2011). This enables a relatively better comparison of countries with different currencies. EU27 represents the average for the whole European Union.

Based on these data, Polish consumers were the poorest (of the three countries) before the economic 


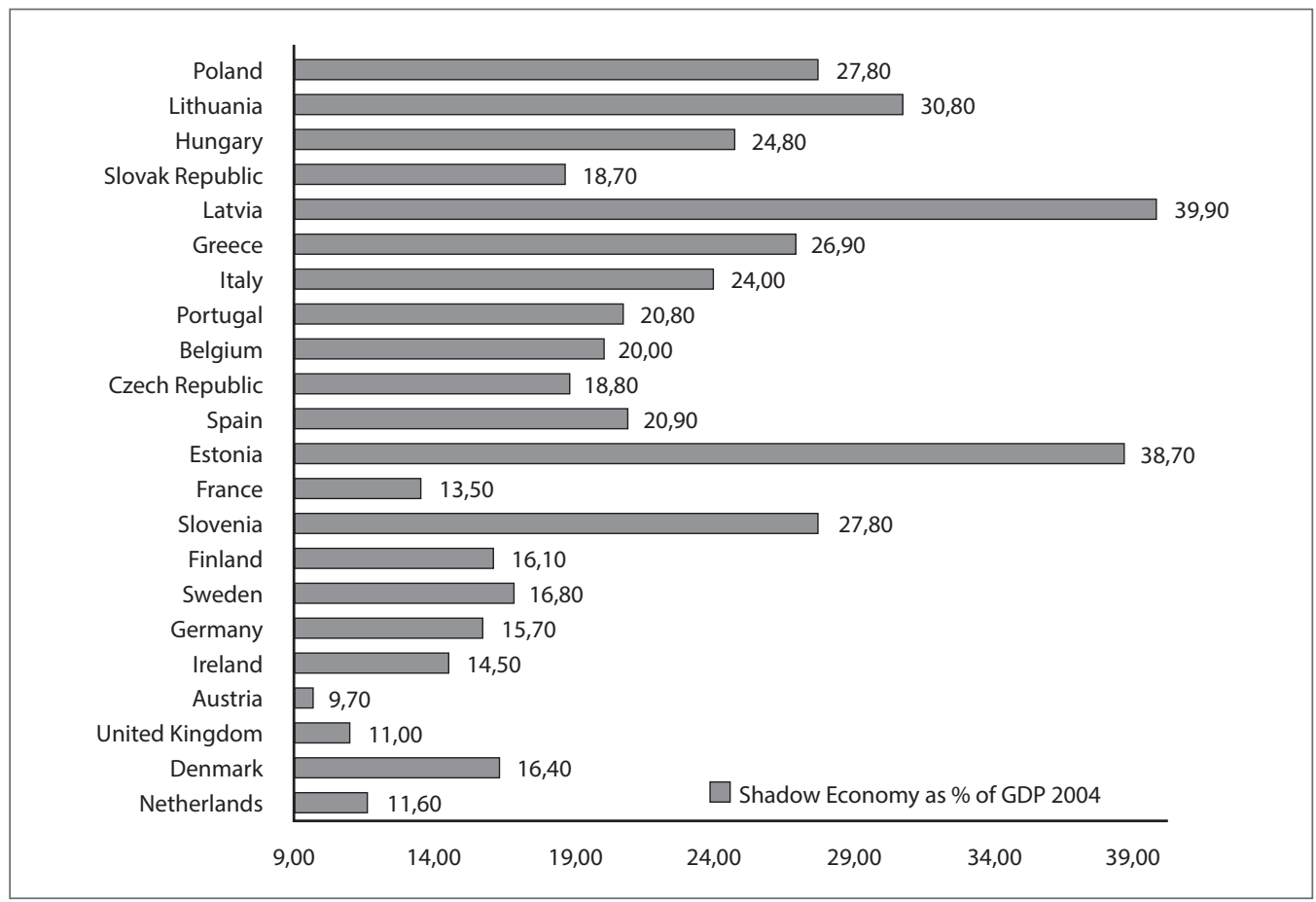

Figure 1. Shadow Economy Relative To GDP in 2004. Schneider, F. (2005). Shadow economies around the world: what do we really know? European Journal of Political Economy, 21(3), 598-642.

recession occurred. However, while Polish consumption was approximately $5.5 \%$ lower compared to Hungary, they were both far behind Spain, where consumption was at the EU's average level. Changes in disposable income in the three countries differed substantially. While disposable income increased in Poland, Hungary experienced a noticeable decline and Spain performed somewhat better than the European mean.

\section{Shadow Economy}

As noted in the literature review, black markets may play a crucial role during a recession. The following data were obtained from OECD research on this subject. Although accurate figures on the shadow economy's impact on the official one are difficult to obtain, there are tools available to provide a sophisticated estimate. The most substantial remaining problem is the lack of any feasible means of validation.

Tafenau, Herwartz and Schneider (2010, p. 2) conducted a study in which they combined a multiple indicators, multiple causes (MIMC) model with aspects of spatial econometrics to diminish the error rate. Additionally, these researchers provided the first estimates of the size of shadow economies in 238 European Union regions using NUTS 2 (Nomenclature of Territorial Units for Statistics 2) classifications. However, the topic has received insufficient scholarly, and the methods to examine it are being constantly revised to deliver more precise data.

In the MIMC model, the "shadow economy is formalized as the outcome of its causes like tax rates and the degree of regulation or unemployment on the one hand. On the other hand, there are variables thought to indicate the size of the shadow economy, for instance, currency ratios or the rate of labour force participation" (Herwatz, Schneider and Tafenau, 2010, p. 3).

The use of the NUTS 2 classification means that regions with populations of between 800 thousand to 3 million inhabitants were taken into consideration (European Parliament, 2003). The researchers were able to estimate each region's shadow economy level relative to the official GDP level (Figure 1). The study also permits 
a comparison of different calculation methods. Although the data concern 2004, they depict the situation when the global economic situation was fairly stable.

Using a slightly different method, Schneider (2005, p. 3) was able to estimate unofficial economy levels for the 1999-2006 period for transition countries including Hungary and Poland. A downward trend was observed, showing that the black market is weaker when the official economy is in a boom, as in Hungary and Poland.

Regardless of the method used, it is clear that Poland has one of the largest unofficial economies in $\mathrm{Eu}-$ rope. Schneider $(2005$, p. 2$)$ found that the scope of the unofficial economy declined as the official economy boomed. The figures for the percentage of the unofficial economy in overall economic activity in 2006 were $26.5 \%$ and $24.4 \%$ for Poland and Hungary, respectively. Assuming that this trend was substantially reversed during the economic downturn, the Polish GDP would have to be adjusted by up to approximately $30 \%$, while the Hungarian and Spanish adjustments would be approximately $25 \%$ and $20 \%$, respectively (Figure 1).

However, the data are not consistent with the theoretical assumptions. Despite the size of the shadow economy in Spain being the lowest of the three countries, Spain was the most affected from the GDP growth point of view. The Hungarian economy contracted to the greatest extent. With the largest unofficial economy, Poland was able to maintain low but positive growth. However, countries with significantly larger shadow economies also suffered from the recession.

This suggests that a shadow economy's 'cushion' effect may have limitations, such as the overall size of the economy. This factor alone cannot be responsible for Polish GDP growth during the recent crunch, but it should not be omitted.

\section{Conclusions}

Private consumption plays a crucial role in GDP formation. This is especially the case in Poland, where private consumption accounted for over $60 \%$ of GDP. This share was higher than those of Spain and Hungary. Interestingly, consumption patterns remained unchanged during the 2007-2009 period. This result means that households spent money in the same way they did prior to the global recession. Therefore, only less expensive or more efficient substitutes were selected, or suppliers decreased their prices to make their products more affordable.
The fact that consumption patterns remained constant in all of the countries studied throughout the 2007-2009 period seems to support the theories presented above. It also appears that all types of consumption, irrespective of importance, changed in nominal terms but the proportions remained constant. It is also important to note that Polish consumption was primarily devoted to basic needs, such as housing, food and drink, or transportation. These goods may be considered necessities. Thus, it could be argued that the increase in Polish consumption might have been sustained by the relatively high prices of basic needs rather than a general propensity to spend.

Based on the relevant literature, 3 main factors were considered factors influencing consumption levels.

Disposable income represents the amount that households had available for consumption. Of the three selected countries, Polish consumers were the poorest; however, not only did Polish consumers not reduce spending, they increased it. This might have been due to a reduced tendency towards savings. In contrast to their Spanish and Hungarian counterparts, Polish consumers began to increase spending rather than savings. Reduced savings during a period of uncertainty seem to contradict prior theories on the subject. Another question of strategic value arises from the theoretical argument that lower savings may be hazardous for a particular economy in the long run. Poland exhibits different characteristics from the situation in 1992 when consumers were sensitive to shortrun shocks (Gorecki, 1994, p. 3)

Polish consumers also did not lose the confidence in the economy and remained generally optimistic. They had strong positive expectations for the future, and while this positivity declined, it did not do so to the extent observable in Spain and Hungary, which remained the most pessimistic. Optimism supported by relatively low unemployment, especially long-term unemployment, appears to have contributed to growth in Poland. The CCI was the lowest in Hungary, and this country reported the greatest decline in GDP. The role of consumption in GDP formation diminished the most in Spain.

The shadow economy might have been responsible for dampening the effects of the economic downturn. Assuming that the estimates were correct, Polish GDP values should have increased by nearly one fourth. Al- 
though Hungary and Spain were also believed to possess well-developed grey markets, those countries suffered from decreases in consumption. Unfortunately, due to the illegal nature of this phenomenon, it is difficult to determine its actual influence. It can be treated as a supplementary factor to be used in conjunction with general consumption attitudes.

In summary, it seems that, unlike that in other countries, Polish consumption was rather unaffected by the global recession. Moreover, Poland reported an increase in consumption. It appears that this increase was primarily the result of high Polish morale. Confidence in the economy and a general propensity to spend rather than save was connected to the availability of credit. Additionally, relatively low unemployment also helped to sustain consumption.

\section{References}

Aron, J., \& Muellbauer, J. (2000). Personal and Corporate Saving in South Africa. The World Bank Economic Review, 14(3), 509-544.

Barhoumi, K., Brunhes-Lesage, V., Darné, O., Ferrara, L., Pluyaud, B., Rouvreau, B. (2007). Monthly forecasting of French GDP: a revised version of the OPTIM model Forecasting short-term economic developments and the role of economic models. Retrieved from Bank of Canada website http://www.bankofcanada. ca/wp-content/uploads/2010/09/pluyaud.pdf

Baxter, M., \& Jermann, U. J. (1999). Household production and the excess sensitivity of consumption to current income. The American Economic Review 89(4), 902-920.

Chowdhury, A. R. (2004). Private Savings in Transition Economies: Are there Terms of Trade Shocks?. Comparative Economic Studies, 46(4), 487-514.

Dreger, C., \& Reimers, H. E. (2006). Consumption and disposable income in the EU countries: the role of wealth effects. Empirica, 33(4), 245-254.

Eurostat (2011). Statistical data on GDP, Unemployment, Private Consumption, Disposable Income in Spain, Hungary and Poland retrieved from: www.eurostat.org.

Euromonitor (n.d.) Euromonitor on economies of Spain, Hungary and Poland, Available from www. eurmonitor.org.

European Parliament. (2003). Regulation(EC) No. 1059/2003 Of the European Parliament and of the
Council of 26 May 2003 on the establishment of a common classification of territorial units for statistics (NUTS) retrieved from eur-lex.europa.eu.

GFK. (2009) Report on Polish gastronomy market, retrieved from www.gfk.pl.

Gorecki, B. (1994). Evidence of a New Shape of Income Distribution in Poland, Eastern European Economics, 32(3), 32-51.

Hungarian Office of Statistics (2011). Data on Hungarian economy, www.ksh.hu/?lang=en

Jenkins, S. P. (2000). Modeling Household Income Dynamics. Journal of Population Economics, 13(4), 529-567.

Kantor, B. (1979). Rational Expectations and Economic Thought. Journal of Economic Literature, 17(4), 1422-1441.

Ludvigson, S.C. (2004). Consumer Confidence and Consumer Spending. The Journal of Economic Perspectives, 18(2), 29-50.

Merriam-Webster's $11^{\text {th }}$ Collegiate Dictionary 2004, entry: consumption

OECD (2007),(2011). Disposable income in EU retrieved from: www.oecd.org

Paap, R., \& van Dijk, H. K. (2003). Bayes Estimates of Markov Trends in Possibly Cointegrated Series: An Application to U.S. Consumption and Income. Journal of Business \& Economic Statistics, 21(4), 547-563.

Polish Office of Statistics (2011). Data on Polish economy retrieved from www.stat.gov.pl/gus/index ENG_HTML.htm

Samuelson, P. A., \& Nordhaus, W. D. (1992). Economics $\left(14^{\text {th }} \mathrm{ed}\right.$.). New York, NY: McGraw-Hill, Inc.

Schneider, F. (2005). Shadow economies around the world: what do we really know? European Journal of Political Economy, 21(3), 598-642.

Schneider, F., \& Enste, D. H. (2000). Shadow Economies: Size, Causes and Consequences. Journal of Economic Literature, 38(1), 77-114.

Schmidt-Hebbel, K., Webb, S. B., \& Corsetti, G. (1992). Household Saving in Developing Countries: First Cross-Country Evidence. The World Bank Economic Review, 6(3), 529-547.

Smith, P. (1994). Assessing the Size of the Underground Economy: The Canadian Statistical Perspectives. Canadian Economic Observer, Cat. No. 13-604, no. 28. 
Spanish Office of Statistics (2011). Data on Spanish economy, retrieved from www.ine.es/en/welcome_en.htm

Stephens, M. Jr. (2004). Job Loss Expectations, Realizations, and Household Consumption Behaviour. The Review of Economics and Statistics, 86(1), 253-269.

Tafenau, E., Herwartz, H., \& Schneider, F. (2010). Regional Estimates of the Shadow Economy in Europe. International Economic Journal, 24(4), 629-636.

Thomas, J. J. (1999). Quantifying the Black Economy:' Measurement without Theory' Yet Again?. The Economic Journal, 109(456), 381-389.

Trading Economies. (2011). Data on Consumer Expectations, available from www.tradingeconomies.com.

Wolnicki, M., Kwiatkowski, E., Piasecki, R. (2006). Jobless growth: a new challenge for the transition economy of Poland. International Journal of Social Economics, 33(3), 192-206.

Zalega T. (2007). Konsumpcja - Podstawy teoretyczne [Consumption - theoretical basis]. Warsaw: Wydawnictwo Naukowe Wydziału Zarządzania Uniwersytetu Warszawskiego. 